\title{
Serhiy Zhadan
}

\section{The Rhinoceros |}

\section{The Cellist}

Translated from Ukrainian to German

by Claudia Dathe

Translated from German to English by Elizabeth Sokol 



\section{The Rhinoceros}

For half a year she remains brave.

For half a year she gazes at death

like a rhino in the zoo-

dark wrinkles,

heavy breathing.

She is fearful, but she looks on,

she does not close her eyes.

Bad, truly bad.

It cannot be otherwise.

Death is bad, it creates fear.

It is bad to breathe the stench of the red moon.

It is bad to see how history arises.

Half a year ago everything was completely different.

Half a year ago everyone was different.

Nobody was frightened by the stars

that fell in the reservoirs.

Nobody was terrified by the fumes,

that rose from the cracks in the black floor.

In the middle of the nightly street, between noise and fire, between death and love, she digs her face into his shoulder, thrashes him with desperate fists, cries and screams in the dark.

I don't want to see any of this, she says, I cannot schlep all this around with me.

What's all the death to me?

How do I start with it?

How do you start with death?

Carry death on your back,

like a gypsy child 
who is not loved by anyone

and does not love anyone?

Love is so scarce,

love is so defenseless.

Weep and partition the dark with your warm hands.

Weep and do not with one step leave his side.

The world will never be as it was.

We will not allow it

to be as it was.

Fewer and fewer bright windows on the empty street.

Fewer and fewer carefree passers-by

in front of the shops' displays.

In the diabolical autumn fog, fields and rivers grow cold.

The fires go out in the rain.

At night the cities die of frost. 


\section{The Cellist}

The cellist drags

his wooden instrument,

stands still,

takes a breath,

barely holds himself up,

drags his legs

across the stony pavement.

How they just yell

in his face,

how they angrily pursue him,

surround him,

hurl curses at him.

Men run together,

women stand annoyed,

children throw pavement lemons

made of gold.

How many bitter words

he has heard in his life.

As if it were his fault

that he has to drag this devil's music,

his fault that he

cannot cast it off

in the middle of the street.

But whom can you make grasp this, to whom can you explain it?

Screams tear the air,

Soon blood runs,

soon tears roll.

The men frown,

the women make noise,

the children imprint the sky into their memory 
until the end

of their long days.

When they then leave

the city, stop on

the hill, he puts

his instrument on the ground,

takes the bow,

bends over the varnished wood,

grows one with it,

cannot tear himself away,

the movements are difficult,

on the battered palms of his hands,

blood congeals.

Then

the men weep,

the hearts of the women wilt,

the children wonder when

pearls

of musical hearing

grow in their fists.

$24+$ Absinthe 27 